\title{
Procedure Subcategory
}

National Cancer Institute

\section{Source}

National Cancer Institute. Procedure Subcategory. NCI Thesaurus. Code C117514.

A subdivision of a procedure event. 